\title{
Development of A Four-Tier Diagnostic Test For Misconception of Oscillation and Waves
}

\author{
Ridho Adi Negoro, ${ }^{1, a)}$, Viga Karina ${ }^{2, b)}$ \\ ${ }^{1}$ Physics Education, Postgraduate, Universitas Negeri Semarang, Indonesia \\ ${ }^{2}$ SMA Negeri 8 Semarang, Indonesia

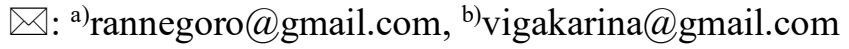

\begin{abstract}
Difficulty understanding students' concepts needs to be known so that improvements can be made so that eventually students can master the concepts well. Misconception diagnostic tests can be an alternative to uncovering causes or factors of misconception in students. This study aims to develop a Four-Tier Test diagnostic test instrument to diagnose students' misconceptions on vibration and wave material to adapt the Mechanical Waves Conceptual Survey by Thongchai which has content compatibility with the segmentation of Indonesian curriculum material. This research is a development study using 3D development models. The 3D development model consists of 3 stages, namely: 1) Define, 2) Design and 3) Develop. The developed four-tier test diagnostic test instrument consists of 22 multiple-choice questions. The results of the content validation by three experts stated that the instrument was very feasible with an average percentage of $87 \%$. Empirical trial results show as many as 22 valid diagnostic test items have enough to good power a level of difficulty and discrimination power. The reliability of the questions was analyzed using the Kuder Richardson formula of 0.765 with a high category. This instrument can be used to minimize the time spent in the process of identifying misconceptions because it is in the form of multiple-choice with varied questions.
\end{abstract}

Keywords: Diagnostic test, misconception, four-tier test, oscillation, waves

\section{INTRODUCTION}

The concept is an abstract framework of the characteristics of things, objects, events or phenomena, situations, which are understood and facilitates communication between human beings that involve thinking processes (cognitive). Concepts can be considered as a way to categorize and understand the world around us and concepts are needed for understanding interpretations about something (Chi 2009; Streveler 2008). Holyoak (2005) states cognitive scientists generally agree that concepts are mental representations that choose groups of entities, or categories. Categorization is an important cognitive function and plays a key role in our understanding and ability to draw conclusions or make predictions (Prince, M, Vigeant, M, \& Nottis, K 2012). In learning physics, mastery of good concepts is very closely related to learning achievement and scientific consistency. Both are very important where learning achievement is an indicator of comprehensive learning outcomes while scientific consistency is the basis for the discipline to apply scientific principles (Krishnayanti, R, Feranie, S, \& Padri, IM 2015; Permata, A, Feranie, S, \& Karim, S 2015). So mastery of concepts is one of the most important parts to consider in learning.

The misconception has a concept definition that is not following with scientific understanding or understanding agreed upon by scientists in a scientific field. Suparno (2013) views misconception as a 
proper understanding of agreed concepts/consensus and hierarchical relationships of concepts that are not appropriate. In learning physics, misconceptions are very easy to find. That is because the conception of physics material is classified as abstract. Based on observations, it was found that in SMA N 8 Semarang on some physics materials, the low learning outcomes of students were also caused by misconceptions.

In the course of learning physics, there are still many cases of vibration and wave material misconceptions found in high school students (Tongchai, Sharma, Johnston, Arayathanitkul, Soankwan 2009; Caleon, IS \& Subramaniam, R 2010; Kryjevskaia 2012). Wave sub-content such as propagation, superposition, reflection, and standing waves are still the most crucial part of the emergence of cases of misconceptions in students (Tongchai, A, Sharma, MD, Johnston, ID, Arayathanitkul, K, \& Soankwan, C 2009). Based on this we need a test instrument that can uncover the most critical factor of students in mastering the concepts of wave material. This is important to improve the quality of physics learning so that the main material can be delivered or mastered well by students.

Measuring the level of understanding and identifying misunderstandings among students is as important as teaching concepts (Bayrak, 2013). Various types of assessment are used in science education to identify students' alternative conceptions such as interviews (Montfort, Brown and Pollock, 2009; Thompson and Logue, 2006), open-ended question (Çalik, Ayas 2005; Chou 2002; Tsaparlis and Papaphotis 2009), and multiple-choice (Uzuntiryaki and Geban, 2005), all of which have advantages and disadvantages in practical use (Tsai, CC, Chou, C 2002). Ariani (2015), Nurul, Samsudin, and Gina (2017) in his research examines misconceptions with diagnostic tests using multiple-choice questions about misconceptions and concludes that the tests used are valid to measure misconceptions.

Multiple-choice tests are often preferred in science classes because they are easy to apply and can evaluate students' understanding of related subjects; however, multiple-choice tests have some limitations in applying such as determining whether a student responds correctly to the test consciously or only by chance in choosing answers. Liu, Lee and Linn (2011) researching on multiple-choice test innovations accompanied by explanation explains that EMC (Explanation Multiple-Choice) items are easier than response/essay items made but more complicated than most multiple-choice items. In the simplest terms, a concept inventory is an outline of core knowledge and concepts for a particular field and a collection of multiple-choice questions designed to explore students' understanding of these fundamental concepts (Redish 2003). In general EMC on multiple-choice is able to overcome the nature of student answers that are classified as coincidence. Furthermore, this EMC is referred to as a three-tier diagnostic test.

Several studies develop a three-tier diagnostic test on physics materials including Eryilmaz and Surmeli (2002); Peşman and Eryilmaz (2010); Cetin-Dindar and Geban (2011); Peşman and Eryilmaz (2010). Then in the last 5 years, many have developed Four Tier diagnostic tests as they were done Annisak, Astalini, and Pathoni, (2017); Zaleha, Samsudin, and Nugraha, (2017) which adds a level of confidence to the explanation of the answer or EMC. Tests related to established misconceptions are like conceptual tests in some physical matter such as Maloney et al., (2001) and has guided the statistical analysis needed in the development of misconception test instruments.

This study aims to develop a four-tier diagnostic test on vibration and wave material that adapts the Mechanical Waves Conceptual Survey content (Tongchai, Sharma, Johnston, Arayathanitkul and Soankwan 2009). Previous studies on dynamic fluid material, particularly the continuity sub-material, identified misconceptions using a four-tier diagnostic test instrument of 28\% (Solihat, F, Samsudin, A, Nugraha 2017). The content raised in the Mechanical Waves Conceptual Survey is propagation, superposition, reflection, and standing waves in accordance with the segmentation of material in the secondary school physics curriculum in Indonesia. Besides, all four content is covered in the most firstyear university physics studies programs and is used as a basis for engineering or engineering education, life science students, and so on.

\section{METHODS}

This research is categorized as development research. The learning tool developed is a four-tier test diagnostic test to measure students' misconceptions about vibration and wave material. The 
development model used is the 3D (four $\mathrm{D}$ model) development model by (Thiagarajan and others, 1974). The 3D development model consists of three main stages, namely: (1) Define, (2) Design, (3) Develop.

At the beginning of the activity, an analysis of potential and problems was carried out in the critical analysis of the misconceptions of the content of the vibrations and waves of junior high school students who often appeared. The data obtained are analyzed and used as a reference to design diagnostic tests for misconceptions of vibration and wave material. In the study, a field trial was conducted at Semarang 8 High School in 2018/2019 academic year involving 32 students of Natural Sciences class XI using a simple random sampling technique.

Data collection is done through non-test techniques, namely the examination of test instruments by material experts and evaluation experts (expert judgment) to determine the validity of the content in terms of material aspects and construction aspects in the form of conformity between questions in the test with indicators, and aspects of language/culture. The results of the content validity through the expert material and expert judgment expert evaluation were analyzed using the formula (Anas 2008).

information:

$$
P=\frac{f}{N} x 100 \%
$$

$$
\begin{array}{ll}
P & =\text { assessment percentage } \\
f & =\text { score obtained } \\
N & =\text { overall score }
\end{array}
$$

The criteria are as follows:

TABLE 1. Eligibility Criteria

\begin{tabular}{cc}
\hline Percentage & Information \\
\hline $85 \%<$ value $\leq 100 \%$ & very decent \\
$70 \%<$ value $\leq 85 \%$ & decent \\
$50 \%<$ value $\leq 70 \%$ & pretty decent \\
$1 \%<$ value $\leq 50 \%$ & not feasible \\
\hline
\end{tabular}

Data analysis was used to obtain the empirical validity of diagnostic tests. The empirical information is the different power of the questions, the level of difficulty of the questions, and other things that affect the validity and reliability of the questions. Item validity is sought by correlating item scores with total scores (product-moment coefficients). The reliability test was carried out using the Kuder Richardson formula, which was used for objective shaped instruments with Arikunto's scales (2002).

\section{RESULTS AND DISCUSSIONS}

\section{Define}

Diagnostic tools have been developed and used to overcome the problem of overcoming difficulties encountered in the interview and open testing process (Gurel, Eryilmaz \& McDermott 2015). The development of a four-tier test diagnostic test instrument uses a 3D development model, with the results of the study as follows.

Based on the identification of problems and data collection that has been done, the researcher decides to develop a student misconception diagnostic test instrument, which is then called the fourtier test misconception diagnostic test instrument. This four-tier test diagnostic test instrument adapted the Mechanical Waves Conceptual Survey (Tongchai, Sharma, Johnston, Arayathanitkul \& Soankwan 2009). The defining steps taken by the researchers are: 1) The research subjects are high school students of class XI Science, 2) The form of the test in the form of four-tier test, 3) the test instrument has 22 items about questions, and 4) The test material is vibration and wave.

\section{Design}

The design stage in making the misconception diagnostic test instrument is as follows: 1) Determine the material, 2) Make a grid of diagnostic test questions, 3) Write a four-tier test question consisting of 
questions, choice of answers, level of confidence in the answers, choice of reasons, and the level of confidence in the reasons as shown in FIGURE 1.

1.1. Problem description

A. (Answer Choice)

B. (Answer Choice)

C. (Answer Choice)

D. (Answer Choice)

E. (the blank selection that can be filled by yourself)

1.2 Level of Confidence in 1.1

A. Sure

B. Not Sure

1.3 Reasons Based on Choices Answer on 1.1

A. (Answer Choice)

B. (Answer Choice)

C. (Answer Choice)

D. (Answer Choice)

E. (the blank selection that can be filled by yourself)

1.4 Level of Confidence in 1.3

A. Sure

B. Not Sure

FIGURE 1. Four-Tier Test Format

\section{Develop}

The items developed to consist of four levels, namely questions, choice of answers, level of confidence in answers, choice of reasons, and level of confidence in reason. The number of questions developed was 22 items with sub-topics used, namely vibration and waves.

After the questions are finished, the next is the instrument validation conducted by the expert in the form of material/content validation. Validation was carried out by three experts to determine whether the instruments used were feasible. The results of the expert assessment are presented in TABLE 2. The trial was conducted in class XI IPA, totaling 32 students. Students are asked to work on misconceptions diagnostic test questions, and the results of student work are then analyzed. The results of validation, different power, and the level of difficulty of 22 questions tested can be seen in TABLE 2. Based on TABLE 2 it can be concluded that 22 questions in the empirical test have a sufficiently high to very high validity level, the difference in power is quite good until very good, the level of difficulty easy to moderate. Moreover, the overall reliability test results of 0.765 included in high category.

TABLE 2.Result of Content Validity

\begin{tabular}{ccccc}
\hline Validator & Content (\%) & Construct (\%) & Language (\%) & Average (\%) \\
\hline Validator 1 & 90 & 85 & 88 & $88 \%$ \\
Validator 2 & 89 & 83 & 90 & $87 \%$ \\
Validator 3 & 87 & 84 & 87 & $86 \%$ \\
Criteria & Very decent & Decent & Decent & Very decent \\
\hline
\end{tabular}

Apart from the advantages of multiple-choice tests in general, there are some drawbacks that need attention.Chu et al., (2010) states certain limitations and drawbacks of multiple-choice questions, such as (1) Students' guesses contribute to error variance and reduce test reliability. (2) The choices chosen do not provide deep insight into students' ideas or conceptual understanding, (3) Students are forced to choose each answer from a very limited list of choices, which prevents them from constructing, organizing and presenting their own answers, (4) it is challenging to write good multiple-choice questions.

TABLE 3. Diagnostic Test Results (Empirical) 


\begin{tabular}{cccc}
\hline No. & Validity & $\begin{array}{c}\text { Discrimination } \\
\text { Power }\end{array}$ & $\begin{array}{c}\text { Tingkat } \\
\text { Kesukaran }\end{array}$ \\
\hline 1 & 0.476 & 0.42 & 0.55 \\
2 & 0.534 & 0.36 & 0.66 \\
3 & 0.643 & 0.34 & 0.57 \\
4 & 0.734 & 0.43 & 0.75 \\
5 & 0.324 & 0.46 & 0.65 \\
6 & 0.543 & 0.37 & 0.43 \\
7 & 0.765 & 0.31 & 0.33 \\
8 & 0.547 & 0.53 & 0.45 \\
9 & 0.765 & 0.42 & 0.34 \\
10 & 0.657 & 0.49 & 0.44 \\
11 & 0.765 & 0.48 & 0.49 \\
12 & 0.698 & 0.51 & 0.69 \\
13 & 0.724 & 0.44 & 0.45 \\
14 & 0.713 & 0.49 & 0.67 \\
15 & 0.744 & 0.45 & 0.51 \\
16 & 0.792 & 0.47 & 0.47 \\
17 & 0.836 & 0.38 & 0.55 \\
18 & 0.741 & 0.47 & 0.56 \\
19 & 0.684 & 0.49 & 0.47 \\
20 & 0.586 & 0.52 & 0.58 \\
21 & 0.641 & 0.55 & 0.54 \\
22 & 0.766 & 0.45 & 0.48 \\
\hline
\end{tabular}

In this developed diagnostic test to minimize these deficiencies by (1) Considering guessed answers from students by making assessment indicators in the form of a combination of answers which are then categorized; (2) Comprehensive and varied (new) question descriptions of the developed diagnostic tests will be able to give students new insights; (3) Free space is provided for students to answer which is another optional which is not available. Sample questions to describe how this test reduces the possibility of guessing answers on students can be seen in FIGURE 2.

Based on the description of the deficiencies and how the developed test is able to coordinate the problem so that in the future, to uncover misconceptions in students required a four-tier form of diagnostic tests that are different from the usual multiple-choice tests that cannot distinguish the correct answers due to the correct reasons from those caused by wrong reason (Caleon and Subramaniam 2010; Pesman and Eryilmaz 2010). 


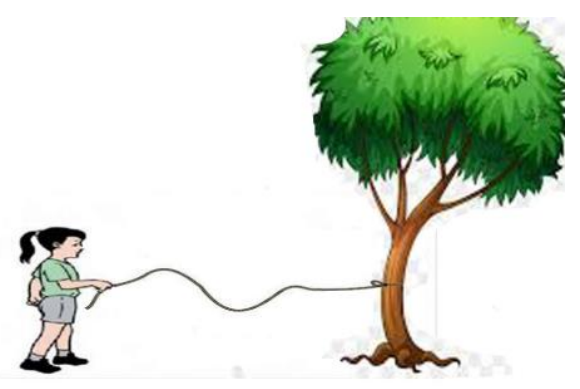

Hanna ties a rope to a tree and is stretched like in the picture. Then Hanna moves the rope up and down, it's creating a pulse that moves towards the tree where the rope is attached. The pulses reach the tree at a time called $\mathrm{t}$.

How does Hanna shorten the time for pulses to reach the tree?
A. Increase rope tension
B. Speed up and down the rope
C. Widen the movement up and down the rope
D. Lacing the rope harder
E.

Are you sure about your choice of answers?
A. Sure
B. Not Sure

I wonder what is the reason you chose that answer?
A. Rope tension affects the wave velocity of a medium
B. the frequency increases, so the pulse speed will increase
C. A large amplitude will increase energy so that the wave velocity increases
D. Hard weak pulse pounding increases energy so that the wave velocity increases
E.

Are you sure about your reasons?
A. Sure
B. Not Sure

FIGURE 2. Four-Tier diagnostic test sample form

\section{CONCLUSIONS}

Based on the research results, it can be concluded that the four-tier form of misconception diagnostic tests is feasible to use and valid based on empirical tests or validity that have a sufficiently high to a very high level of validity, different enough to very good question power, easy to moderate difficulty levels. And the overall reliability test results of 0.765 included in the high category. Based on the results, it is also known that the four-tiered form of diagnostic tests developed was able to map the conceptions of each material content of vibrations and waves as a reference for evaluating physics learning.

\section{REFERENCES}

Anas, S 2008, Pengantar statistik pendidikan, Raja Grafindo Persada, Jakarta.

Annisak, W, Astalini, Pathoni, H 2017, 'Desain Pengemasan Tes Diagnostik Miskonsepsi Berbasis

CBT ( Computer Based Test )', EduFisika, vol. 2, no. 1, pp. 1-12.

Ariani, T 2015, Identifikasi Miskonsepsi Siswa dalam Pembelajaran Fisika pada Pokok Bahasan Listrik Dinamis di SMA Negeri 2 Banda Aceh, ETD Unsyiah.

Arikunto, S 2002, Metodologi penelitian, PT. Rineka Cipta, Jakarta. 
Bayrak, BK 2013, 'Using two-tier test to identify primary student's conceptual understanding and alternative conceptions in acid base', Mevlana International Journal of Education, vol. 3, no. 2, pp. 19-26. doi: 10.13054/mije.13.21.3.2.

Caleon, IS \& Subramaniam, R 2010, 'Exploring Students Conceptualization of the Propagation of Periodic Waves', The Physics Teacher, vol. 48, no. 55. doi: 10.1119/1.3274366.

Caleon, IS \& Subramaniam, R 2010, 'Development and application of a three-tier diagnostic test to assess secondary students understanding of waves', International journal of science education, Taylor \& Francis, vol. 32, no. 7, pp. 939-961.

Çalik, M \& Ayas, A 2005, 'A Comparison of Level of Understanding of Eighth-Grade Students and Science Student Teachers Related to Selected Chemistry Concepts', Journal of Research in Science Teaching, Wiley Online Library, vol. 42, no. 6, pp. 638-667.

Cetin-Dindar, A \& Geban, O 2011, 'Development of a three-tier test to assess high school students understanding of acids and bases', Procedia-Social and Behavioral Sciences, Elsevier, vol. 15, pp. 600-604.

Chi, MTH 2009, 'Three types of conceptual change: Belief revision, mental model transformation, and categorical shift', in International handbook of research on conceptual change, Routledge, pp. 89110.

Chou, CY 2002, 'Science Teachers' Understanding of Concepts in Chemistry', PROCEEDINGSNATIONAL SCIENCE COUNCIL REPUBLIC OF CHINA PART D MATHEMATICS SCIENCE AND TECHNOLOGY EDUCATION. CHINA NATIONAL SCIENCE COUNCIL, 12(2), pp. 7378.

Chu, HC 2010, 'A two-tier test approach to developing location-aware mobile learning systems for natural science courses', Computers and Education, Elsevier Ltd, vol. 55, no. 4, pp. 1618-1627. doi: 10.1016/j.compedu.2010.07.004.

Eryilmaz, A \& Surmeli, E 2002, 'Assessment of students misconceptions about heat and temperature by means of three-tier questions', Retrieved April, vol. 5, p. 2004.

Gurel, DK, Eryilmaz, A, \& McDermott, LC 2015, 'A review and comparison of diagnostic instruments to identify students' misconceptions in science', Eurasia Journal of Mathematics, Science and Technology Education, vol. 11, no. 5, pp. 989-1008. doi: 10.12973/eurasia.2015.1369a.

Holyoak, KJ, Morrison, RG, \& Others 2005, Thinking and Reasoning: A Readers Guide, Citeseer.

Krishnayanti, R, Feranie, S, \& Padri, IM 2015, 'Penerapan Five Stage Conceptual Teaching Model untuk Meningkatkan Prestasi Belajar dan Konsistensi Ilmiah pada Siswa SMA', vol. 1, pp. 25-30.

Kryjevskaia, M 2012, 'Student understanding of wave behavior at a boundary: The relationships among wavelength, propagation speed, and frequency', American Journal of Physics, vol. 80, no. 4, pp. 339-347.

Liu, OL, Lee, HS, \& Linn, MC 2011, 'An investigation of explanation multiple-choice items in science assessment', Educational Assessment, vol. 16, no. 3, pp. 164-184. doi: 10.1080/10627197.2011.611702.

Montfort, D, Brown, S, \& Pollock, D 2009, 'An investigation of students' conceptual understanding In related sophomore to graduate-level engineering and mechanics courses', Journal of Engineering Education, vol. 98, no. 2, pp. 111-129. doi: 10.1002/j.2168-9830.2009.tb01011.x.

Nurul, F, Samsudin, A, \& Gina, M 2017, 'Identifikasi Miskonsepsi dan Penyebab Miskonsepsi Siswa Menggunakan Four-Tier Diagnostic Test pada Sub- Materi Fluida Dinamik : Azas Kontinuitas', vol. 3, pp. 175-180.

Permata, A, Feranie, S, \& Karim, S 2015, 'Penerapan Pembelajaran Berbasis Masalah dengan Pendekatan Multirepresentasi untuk Meningkatkan Prestasi Belajar dan Konsistensi Ilmiah Berbasis Multirepresentasi pada Materi Elastisitas', vol. 1, pp. 45-50. 
Pesman, H, \& Eryilmaz, A 2010, 'Development of a three-tier test to assess misconceptions about simple electric circuits', The Journal of educational research. Taylor \& Francis, vol. 103, no. 3, pp. 208-222. doi: 10.1080/00220670903383002.

Prince, M, Vigeant, M, \& Nottis, K 2012, 'Development of the heat and energy concept inventory: Preliminary results on the prevalence and persistence of engineering students' misconceptions', $J$. Eng. Educ., vol. 101, no. 3, pp. 412-438. doi: 10.1002/j.2168-9830.2012.tb00056.x.

Redish, EF 2003, Teaching physics: with the physics suite, Citeseer.

Sholihat, FN, Samsudin, A, Nugraha, MG 2017, 'Identifikasi Miskonsepsi dan Penyebab Miskonsepsi Siswa Menggunakan Four-Tier Diagnostic Test pada SubMateri Fluida Dinamik: Azas Kontinuitas', Jurnal Penelitian dan Pengembangan Pendidikan Fisika, vol 3, no. 2, 175 - 180, doi: doi.org/10.21009/1.03208

Streveler, RA 2008, 'Learning conceptual knowledge in the engineering sciences: Overview and future research directions', Journal of Engineering Education. Wiley Online Library, vol. 97, 3, pp. 279294.

Suparno, P 2013, Miskonsepsi \& Perubahan Konsep dalam Pendidikan Fisika, Gramedia Widiasarana.

Thiagarajan, S, \& Others 1974, 'Instructional development for training teachers of exceptional children: A sourcebook', ERIC.

Thompson, F, Logue, S 2006, 'An exploration of common student misconceptions in science', International Education Journal, vol. 7, no. 4, pp. 553-559. doi: http://dx.doi.org/10.1016/j.sbspro.2014.07.465.

Tongchai, A, Sharma, MD, Johnston, ID, Arayathanitkul, K, \& Soankwan, C 2009, 'Developing, evaluating and demonstrating the use of a conceptual survey in mechanical waves', International Journal of Science Education. Taylor \& Francis, vol. 31, no. 18, pp. 2437-2457. doi: 10.1080/09500690802389605.

Tsai, CC, Chou, C 2002, 'Diagnosing students' alternative conceptions in science', Journal of Computer Assisted Learning, vol. 18, no. 2, pp. 157-165. doi: 10.1046/j.0266-4909.2002.00223.x.

Tsaparlis, G, Papaphotis, G 2009, 'High-school students' conceptual difficulties and attempts at conceptual change: The case of basic quantum chemical concepts', International Journal of Science Education, vol. 31, no. 7, pp. 895-930. doi: 10.1080/09500690801891908.

Uzuntiryaki, E, Geban, Ö 2005, 'Effect of conceptual change approach accompanied with concept mapping on understanding of solution concepts', Instructional Science, vol. 33, no. 4, pp. 311-339. doi: 10.1007/s11251-005-2812-z.

Zaleha, Z, Samsudin, A,\& Nugraha, MG 2017, 'Pengembangan Instrumen Tes Diagnostik VCCI Bentuk Four-Tier Test pada Konsep Getaran', Jurnal Pendidikan Fisika dan Keilmuan (JPFK), vol. 3, no. 1, p. 36. doi: 10.25273/jpfk.v3i1.980. 